\title{
Right-Sided Adenomas of the Colon: A Risk Factor For High-Grade Dysplasia or Invasive Cancer
}

\author{
Sağ Kolon Yerleşimli Adenomlar: \\ High-Grade Displazi veya Invaziv Kanser için Risk Faktörü
}

\author{
Ahmet Tarlk Eminler', Mustafa Ihsan Uslan', Kader Irak ${ }^{2}$, \\ Talat Ayyıldız², Murat Keskin², Murat Kıyıcı², Selim Gürel², \\ Macit Gülten², Enver Dolar², Selim Giray Nak²
}

${ }^{1}$ Sakarya University Gastroenterology Department

${ }^{2}$ Uludag University Gastroenterology Department

Yazışma Adresi / Corresponding to:

Yard. Doç. Dr. Ahmet Tarık Eminler Sakarya Üniversitesi Tıp Fakültesi Iç Hastalıkları Anabilim Dalı, Korucuk Kampüsü 54000 Sakarya - Türkiye Gsm : 05323415400 e-mail : eminler@yahoo.com

Amaç: Bu çalışmanın amacı high-grade displazi (HGD) ve invaziv kanser ( "ilerlemiş patoloji (iP)" olarak tanımlanmıştır) ile ilişkili multipl hasta ve adenom karakterlerini değerlendirmektir.

Materyal ve Metod: Toplam 6250 işlem sonunda 894 hastada 1379 (\% 22.06) polip mevcuttur. Biz patoloji sonuçlarına ulaşabildiğimiz 914 polipi değerlendirmeye aldik.

Bulgular: 914 polipte toplam 699 adenom tespit edildi. A total of 699 adenomas were detected from 914 polyps. Sağ kolon yerleşimli poliplerde sola göre daha yüksek oranda IP özellikleri bulundu (\% 18.5 vs \% 7.1 p: 0.002). Lojistik regresyon analizi sonucunda; erkek cinsiyet, 2 cm'e eşit ya da büyük boyut, villöz histoloji ve non-dimünitif görünüm adenomlardaki IP özellikleri için bağımsız risk faktörleri olarak bulundu.

Sonuç: Çalışmamızda, diğer çalışmalara benzer olarak, erkek cinsiyet, 2 cm'e eşit ya da büyük boyut, villöz histoloji ve non-dimünitif görünüm adenomlardaki IP özellikleri için bağımsız risk faktörleri olarak bulundu. Fakat diğer birçok çalışmanın aksine biz sağ kolon yerleşimli poliplerde sol taraf yerleşimli poliplere göre daha yüksek oranda IP özellikleri bulduk.

Anahtar Kelimeler: Kolorektal adenomlar, dizplazi, adenokanser

\section{Abstract}

Objectıves: The aim of the study was to evaluate multiple patient and adenoma variables associated with high-grade dyplasia (HGD) and invasive carcinoma. (which were termed as "advanced pathology $\left.(A P)^{\prime \prime}\right)$.

Materials and Methods: In total 6250 processes there were 1379 (22.06 \%) polyps from 894 patients. We evaluated 914 polpys which we could find patholojical results.

Results: A total of 699 adenomas were detected from 914 polyps. We found more higher percantage of AP features at the rigt-sided adenomas than the leftsided (18.5\% vs $7.1 \%$, p: 0.002). According to the logistic regression analysis; male gender, larger or equal $2 \mathrm{~cm}$ diameter, villous histology and non-dimunitive gross appearance were found to be the independent risk factors for the AP features of the adenomas.

Conclusion: In our study, similar to other studies, male gender, larger than $2 \mathrm{~cm}$ adenom diameter, villous component and non-dimunitive gross appearance are the independent risk factors for the AP features of any adenomas. However in contrast to most of the other studies we found higher percentage of AP features at the right-sided adenomas than the left-sided ones.

Keywords: Colorectal adenomas, dysplasia, adenocarcinoma 


\section{Introduction:}

The adenoma-carcinoma sequence is widely accepted as the model of colorectal adenocarcinoma (CRC). However the minority of adenomas undergo malignant transformation which may take 10-20 years. Colonoscopic screening studies in symptomatic people suggest that at age 50 the prevalence of adenomas is $25-30 \%$ and autopsy studies have found rates as high as $50 \%$ at age $70^{1}$.

There are many studies about estimating the malignant potential of the adenomas. Generally it is accepted that adenoma size and histological type are important predictors for the risk of dysplasia or invasive carcinoma².

The aim of the study was to evaluate multiple patient and adenoma variables associated with high-grade dyplasia (HGD) and invasive carcinoma. (which were termed as "advanced pathology (AP)") .

\section{Materials and Methods}

All colonoscopic polyps that removed between February-2005 and July-2010 in Gastoenterology Unit of Uludag University Faculty of Medicine were analysed retrospectively from an archive system. In total 6250 processes there were 1379 (22.06 \%) polyps from 894 patients. We evaluated 914 polpys which we could find patholojical results. Adenomas localized in the rectum, sigmoid colon, descending colon or splenic flexure were designed as left-sided. Adenomas of the transverse colon, hepatic flexure, ascending colon or caecum were designed as right-sided. We divided the adenomas into two groups according to their histopatholojical features (High grade dysplasia (HGD) and adenocarsinoma as AP group and the others as non-AP group). Patients with significant obstructive lesions, which have underlying malignancy or inflammatory bowel disease were excluded.

\section{Statistics}

All statistical analyses were carried out by using SPSS 16 software program. Kolmogorov-Smirnov test was used for the compliance of the normal distribution of data. Comparisons between groups and age were evaluated using the MannWhitney $U$ test. The association between AP and different adenoma characteristics was analysed by the chi-squared test.
Logistic regression was used to study the impact of different adenoma and patient characteristics on the risk of AP. Statistical significance level of $p<0.05$ was considered.

\section{Results}

A total of 699 adenomas were detected from 914 polyps. The mean age was $61.12 \pm 11.5$ years. $59.5 \%$ of the patients who had adenomas were male and $40.5 \%$ were female. $618(88.4 \%)$ of adenomas were detected at left side of the colon and $81(11.6 \%)$ were at right-side. 644 (92.3\%) were smaller than $2 \mathrm{~cm}$ and the others were larger or equal to 2 $\mathrm{cm}(7.7 \%) .412$ of adenomas were (58.9\%) dimunitive and the others were sessile, pedinculated or flat according to their gross appearance. Acoording to the pathology; 621 (89.7\%) adenomas were tubuler, 66 were $(9.5 \%)$ tubulovillous and 5 $(0.7 \%)$ were villous. There were seen no dysplasia in 510 adenomas (73\%) and low-grade dysplasia were detected in the 130 adenomas (18.6\%). 52 adenomas had (7.4\%) high grade dysplasia and 7 adenomas ( $1 \%$ ) were reported as adenocarcinoma (Table-1)

There was no statistically significant difference in terms of

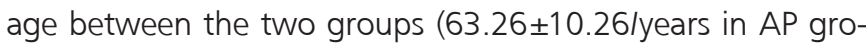
up, 60.92 \pm 11.40 / years in non-AP group, p:0.18). The percentage of adenomas that have AP features was higher in males compared to the females (10.6\% vs 5.3\%, p:0.009). The adenomas that were larger or equal $2 \mathrm{~cm}$ were significantly have more AP features than the smaller ones (30.9\% vs $6.5 \%, p<0.001)$. The percentage of the adenomas that have AP features were increased when the adenomas had more villous component $(26.9 \%$ vs $6.1 \%, p<0.001)$. There were seen more AP features when the gross appearance of the adenomas were non-dimunitive ( $14.3 \%$ vs $4.4 \%, p<0.001$ ). And also we found more higher percantage of AP features at the rigt-sided adenomas than the left-sided $(18.5 \%$ vs $7.1 \%$, p:0.002) (Table-2).

According to the logistic regression analysis; male gender, larger or equal $2 \mathrm{~cm}$ diameter, villous histology and nondimunitive gross appearance were found to be the independent risk factors for the AP features of the adenomas (Table-3). 


\section{Discussion}

It is well known that only a minority of adenomas undergo malignant transformation, and there is evidence that the course of adenomas from mild to moderate to high-grade dysplasia and invasive carcinoma requires at least 10 years 3. The prevalence of advanced colonic adenomas, which are associated with a higher risk of colon cancer, is much lower. In a meta-analysis of average risk individuals, the prevalence was 3.8 percent in patients under age 65 and 8.2 percent in older patients ${ }^{4}$.

HGD is defined in according to the World Health Organization $^{5}$ and includes carcinoma in situ. The pathological feature of high-grade dysplasia (HGD) has been regarded as the bridge between benign adenoma and invasive cancer. Due to ethical considerations, there are almost no prospective in-vivo studies in humans concerning the natural history of colorectal adenomas. Nevertheless, there is convincing evidence that adenomas with high-grade dysplasia run a considerable risk of malignant transformation. Thus, many authors currently use high-grade dysplasia as a marker for high malignant potential ${ }^{3}$. The rate of high-grade dysplasia in adenomas varies widely between different studies ${ }^{6}$. In studies of endoscopically removed adenomas, the malignancy rate is $0.6-4.8 \%(7,8)$. In our study incidence of AP is $8.4 \%$ and the approximately $1 \%$ incidence of adenocancer has been found.

The potential for malignant transformation is 8-10 times higher for villous and tubulovillous adenomas than for tubular adenomas. Just over $1 \%$ of adenomatous polyps $<1 \mathrm{~cm}$ are malignant, whereas up to $40 \%$ of adenomas $>2 \mathrm{~cm}$ are malignant $^{9}$. Also in one study demonstrated that patients who have a colorectal adenoma $>1 \mathrm{~cm}$ with HGD may be at high risk of developing further adenomas with HGD or carcinoma ${ }^{10}$. In a recent study the authors showed that the factors that are associated most strongly with risk of advanced neoplasia are patient age and the number and size of prior adenomas 11. Our results showed a direct correlation between adenoma size $(\geq 2 \mathrm{~cm}$ ) and also increasing villous component and advance histology like other studies.
In clinical studies, the anatomical distribution of adenomas and carcinomas is similar, both occurring more frequently distal to the splenic flexure; adenomas of the left colon more often contain severe dysplasia or invasive adenocarcinoma ${ }^{12}$. From several studies, it is well known that the percentage of adenomas with AP features is higher in the left side than in the right side of the colon and also it is accepted that leftsided location was an independent risk factor for $\mathrm{APF}^{13}$, but this phenomenon has been attributed mostly to the fact that adenomas in the left side of the colon are significantly larger and contain a significantly higher component of villous tissue than their right-sided counterparts. The series of 356 adenomas endoscopically removed in 1980-85 differs from other reports in that $24.4 \%$ of the adenomas were located in the right colon. These adenomas were mostly (79\%) under 5 $\mathrm{mm}$ in diameter, sessile (89\%) and histologically tubular with slight dysplasia (95\%). Only 3 adenomas over $10 \mathrm{~mm}$ in diameter and tubulovillous presented severe dysplasia ${ }^{14}$. In a recent study the authors suggested that the presence of villous or proximal lesions at baseline is associated with increased risk of advanced colonic neoplasia at surveillance ${ }^{15}$.

In our study there was a higher percentage of AP features in the right-sided adenomas compared to the left-sided adenomas $(18.5 \%$ vs $7.1 \%, \mathrm{p}: 0,002)$. There was not any statistically difference according to age, shape, size or pathology between right and left sided adenomas (not shown). So we thought that this finding is different and valuable compared with the past studies.

In conclusion, in our study, similar to other studies, male gender, larger than $2 \mathrm{~cm}$ adenom diameter, villous component and non-dimunitive gross appearance are the independent risk factors for the AP features of any adenomas. However in contrast to most of the other studies we found higher percentage of AP features at the right-sided adenomas than the left-sided ones. Larger prospective studies are thought to be useful to determine the importance of right-sided adenomas about their malignant potential. 


\section{References}

1. Kristjansdottir S, Jonasson JG, Cariglia N, Thjodleifsson B. Colonic adenomas found via colonoscopy: yield and risk factors for high-grade dysplasia. Digestion. 2010;82(4): 252-7

2. Muto T, Bussey HJ, Morson BC. The evolution of cancer of the colon and rectum. Cancer 1975;36: 2251-70.

3. Gschwantler M, Kriwanek S, Langner E, et al. High-grade dysplasia and invasive carcinoma in colorectal adenomas: a multivariate analysis of the impact of adenoma and patient characteristics. Eur J Gastroenterol Hepatol. 2002 Feb; 14(2): 183-8.

4. Heitman SJ, Ronksley PE, Hilsden RJ, et al. Prevalence of adenomas and colorectal cancer in average risk individuals: a systematic review and metaanalysis. Clin Gastroenterol Hepatol 2009;7: 1272-8

5. Hamilton SR Aaltonen LA (eds): World Health Organization Classification of Tumours. Pathology and Genetics of Tumours of the Digestive System. Lyon, IARC Press, 2000.

6. O'Brien MJ, Winawer SJ, Zauber AG, Gottlieb LS, Sternberg SS, Diaz B, et al. The National Polyp Study. Patient and polyp characteristics associated with high-grade dysplasia in colorectal adenomas. Gastroenterology 1990;98: 371-79.

7. Shinya H, Wolff WI. Morphology, anatomic distribution and cancer potential of colonic polyps. Ann Surg 1979;190: 679-83.
8. Rex DK, Lehman GA, Ulbright TM, Smith JJ, Pound DC, Hawes RH. Colonic neoplasia in asymptomatic persons with negative fecal occult blood tests: influence of age, gender, and family history. Am J Gastroenterol 1993;88: 825-31.

9. Cappell MS. The pathophysiology, clinical presentation, and diagnosis of colon cancer and adenomatous polyps. Med Clin N Am 89 (2005) 1-42

10. Toll AD, Fabius D, Hyslop T. Prognostic significance of high-grade dysplasia in colorectal adenomas. Colorectal Dis. 2011 Apr;13(4):370-3

11. Martínez ME, Baron JA, Lieberman DA, Schatzkin A et al. A pooled analysis of advanced colorectal neoplasia diagnoses after colonoscopic polypectomy. Gastroenterology. 2009;136(3):832-41

12. Gillespie PE, Chambers TJ, Chan KW, et al. Colonic adenomas-a colonoscopy survey. Gut 1979;20: 240-5.

13. Nusko G, Mansmann U, Partzsch U. Invasive carcinoma in colorectal adenomas: multivariate analysis of patient and adenoma characteristics. Endoscopy. 1997 Sep;29(7): 626-31.

14. Caruso ML, Di Matteo G, Giorgio P. Adenoma-carcinoma sequence in the right colon. Minerva Dietol Gastroenterol. 1989 Jan-Mar;35(1): 13-6

15. Lee TJ, Nickerson C, Goddard AF et al. Outcome of 12-month surveillance colonoscopy in high-risk patients in the National Health Service Bowel Cancer Screening Programme. Colorectal Dis. 2013 Aug;15(8):e435-42 